\title{
Combinatorial analysis of agronomic characters in soybean
}

\section{Análise combinatoria de caracteres agronomicos em soja}

\author{
Makyslano Rezende da Rocha1* (D), Osvaldo Toshiyuki Hamawaki' (iD), Ana Paula Oliveira Nogueira1 (D), Carlos

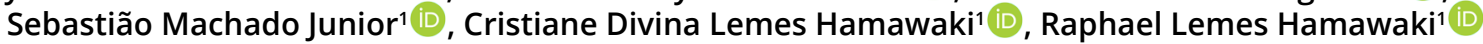

'Universidade Federal de Uberlândia/UFU, Uberlândia, Minas Gerais, Brasil

*Corresponding author: makyslano.rocha@hotmail.com

Received in December 5, 2018 and approved in April 16, 2019

\section{ABSTRACT}

Evaluation of the genetic potential of parent plants is fundamental for obtaining superior populations with desirable agronomic characters. The aim of this work was to obtain estimates of the general and specific combining abilities of five soybean parents to identify the most promising parents and hybrid combinations for the development of superior genotypes for grain yield. In this study, two groups of soybean cultivars were selected: group I resistance (UFUS 7910 and BR/MG 46 Conquista) and group II (TMG 4182, TMG 4185 and BRSGO Chapadões). The parents were crossedin a 2 × 3 partial diallel scheme, and the experiment was analyzed according to Griffing's (1956) parent and $F_{1}$ model and adapted by Geraldi and Miranda Filho (1988). Six hybrid combinations and respective parents were arranged in randomized complete blocks with four repetitions. The following characters were evaluated: number of days for flowering and maturity, height of the plant in flowering and at maturity, number of nodes in flowering and at maturity, number of total pods and grain yield per plant. The BR/MG 46 Conquista, UFUS 7910 and BRSGO Chapadões parents contributed to obtaining productive segregant populations due to additivity for the total number of pods and grain yield per plant. The hybrid combinations BRSGO Chapadões x BR/MG 46 Conquista, BRSGO Chapadões x UFUS 7910 and TMG4182 x BR/MG 46 Conquista are promising for obtaining populations with high productive potential.
\end{abstract}

Index terms: Glycine max; partial diallel; combining ability.

\begin{abstract}
RESUMO
A avaliação do potencial genético dos parentais é fundamental para obter populações superiores para os principais caracteres agronômicos. O objetivo desse trabalho foi obter estimativas das capacidades geral e específica de combinação de cinco genitores de soja, por meio do dialelo parcial, a fim de identificar os parentais e as combinações híbridas mais promissoras para produtividade de grãos. Neste estudo, dois grupos de cultivares foram selecionados: grupo I (UFUS 7910 e BR/MG 46 Conquista) e grupo II (TMG 4182 , TMG 4185 e BRSGO Chapadões). Os parentais foram cruzados em esquema de dialelo parcial $2 \times 3$ e o experimento foi analisado de acordo com o modelo Pais e $F_{1}$ de Griffing (1956) e adaptado por Geraldi e Miranda Filho (1988). Seis combinações híbridas e os respectivos parentais foram conduzidos em delineamento de blocos casualizados, com quatro repetições. Foram avaliados os seguintes caracteres: número de dias para florescimento e para maturidade, altura da planta no florescimento e na maturidade, número de nós no florescimento e na maturidade, número de vagens totais e produção de grãos por planta. Os parentais BR/MG 46 Conquista, UFUS 7910 e BRSGO Chapadões contribuem para a obtenção de populações segregantes produtivas, devido a aditividade para número de vagens totais e produção de grãos por planta. As combinações híbridas BRSGO Chapadões x BR/MG 46 Conquista, BRSGO Chapadões x UFUS 7910 e TMG 4182 x BR/ MG 46 Conquista são promissoras para a obtenção de populações com alto potencial produtivo.
\end{abstract}

Termos para indexação: Glycine max; dialelo parcial; capacidade de combinação.

\section{INTRODUCTION}

The first step in the development of new cultivars is the selection of parents with desirable characters for the accomplishment of crossings aimed at the amplification of genetic variability. Therefore, the evaluation of the genetic potential of the parents is fundamental for obtaining superior populations for the main agronomic characters.
At the beginning of breeding, obtaining the best hybrid combinations may determine the degree of success achieved by breeding programs since the genetic variability in the segregating population should be high, especially for quantitative traits such as grain yield (Bertan; Carvalho; Oliveira, 2007; Akram et al., 2016). Several methods have been proposed with the aim of obtaining superior segregating populations, and among these, diallel crossing has been widely used (Daronch et 
al., 2014; Oliveira et al., 2014; Bi et al., 2015). Among the dialectical analyses that can be used are the methodologies proposed by Griffing (1956), Gardner and Eberhart (1966), and Hayman (1954) and the partial diallel presented by Kempthorne and Curnow (1961).

From the diallel crossings, it is possible to estimate the general combining ability (GCA) and specific combining ability (SCA). The estimates of GCA can indicate a major concentration of genes that are predominantly additives, which in high or low estimates, positive or negative, show that the given parents are much higher or lower than the other parents of the diallel. The estimates of SCA demonstrate a higher predominance of non-additive genes, which characterizes complementation among the parents in relation to the frequencies of dominant alleles, indicating the performance of the hybrid combinations in relation to the genitors. Therefore, these genetic parameters allow an understanding of the nature and magnitude of the genetic effects involved in the determination of characters; in addition, they contribute to the establishment of parental selection strategies, which will result in segregating populations with greater genetic potential (Cruz; Regazzi; Carneiro, 2012).

Partial diallels have been used because of the limitations afforded by the study of large numbers of parents and their hybrid combinations in relation to complete diallels (Cruz; Regazzi; Carneiro, 2012). This method involves evaluating parents in two groups, whether or not they belong to a common set, and provides information on their general and specific combining abilities (Geraldi; Miranda Filho, 1988). In soybean, this method becomes even more advantageous mainly due to the difficulty in obtaining a large number of $F_{1}$ seeds in cross-breeding.

Diallel analyses have been carried out in soybean for the study of oil and protein content (Oliveira et al.,
2014; Nagarajan; Kalaimagal; Murugan, 2017; Painkra; Nag; Khute, 2017) and agronomic traits (Rocha; Pereira; Vello, 2018). However, information on the agronomic characters of early generations of soybean, such as plant height and production components that have effects on grain yield, is still difficult to find. The estimation of genetic parameters for these traits is important to direct crosses and to maximize the genetic variability of the segregating populations in breeding programs.

The aim of this work was to obtain estimates of the general and specific combining abilities of five soybean parents to identify the most promising parents and hybrid combinations for the development of superior genotypes for grain yield.

\section{MATERIAL AND METHODS}

The experiment was conductedin a greenhouse of the Soybean Breeding Program of the Universidade Federal de Uberlândia (UFU), located on the Experimental Farm Capim Branco (18 53'24.5”'S, 48 20'27.1'Wand $805 \mathrm{~m}$ altitude) at Uberlândia, Minas Gerais.

In this study, two groups of soybean cultivars were selected: group I, with root-knot nematode resistance (Meloidogyne incognita and Meloidogyne javanica), and group II, with resistance to different cyst nematode (Heterodera glycines) races. The goal was the development of segregating populations for the selection of superior genotypes (Table 1).

From December 2015 to March 2016, the crossing blocks were implanted with a staggered method every four days to enable synchronization of flowering among the parents. The seeds were sown in plastic pots that had a volume of $3.0 \mathrm{dm}^{-3}$ and that were filled with substrate (soil, sand and organic matter) in a 3:1:1 ratio, and fertilization was performed applying the equivalent of $400.0 \mathrm{~kg} \mathrm{ha}^{-1}$ NPK fertilizer in a 4-30-16 formulation. In each pot, five

Table 1: Description of soybean parents used in the crosses to obtain a partial diallel without reciprocals.

\begin{tabular}{cccc}
\hline Groups & Parental & Resistance & MG \\
\hline \multirow{2}{*}{ Group I } & UFUS 7910 & R: M. incognita and M. javanica & 8.4 \\
& BR/MG 46 Conquista & R: M. incognita and M. javanica & 8.2 \\
\hline \multirow{2}{*}{ Group II } & TMG 4182 & R: $1,2,3,4,5,6,9,10$ and 14 & 8.2 \\
& TMG 4185 & R: $1,3,4,6,9,10$ and $14 ;$ MR: 2 and 5 & 8.5 \\
\hline
\end{tabular}

R: resistant; MR: moderately resistant; MG maturity group. 
seeds were sown for each cultivar, and after stage V1 (fully developed unifoliolate leaves), thinning was performed, maintaining two plants per pot. Periodically, irrigations were performed twice a day manually, and control of diseases and pests was performed weekly with the application of a fungicide (mancozebe, $3.0 \mathrm{~kg} \mathrm{ha}^{-1}$ ) and an insecticide (thiamethoxam / lambda-cyhalothrin, $200.0 \mathrm{~mL} \mathrm{ha}^{-1}$ ).

The crosses were performed in a $2 \times 3$ partial diallel scheme without reciprocal crosses using two groups of parents and obtaining six hybrid combinations (C1: TMG $4182 \times$ BR/MG 46 Conquista; $C 2$ : TMG 4185 x BR/MG 46 Conquista; C3: BRSGO Chapadões x BR/ MG 46 Conquista; C4: TMG 4182 x UFUS 7910; C5: TMG 4182 x UFUS 7910; C6: BRSGO Chapadões x UFUS 7910). The cultivars TMG 4182, TMG 4185 and BRSGO Chapadões were used as female parents because they had white flowers, while UFUS 7910 and BR/MG 46 Conquista, with purple flowers, were used as male parents. For each combination, $18 \mathrm{~F}_{1}$ seeds were obtained.

The hybrid $F_{1}$ 's and parents were seeded on August 16, 2016, in pots that had a capacity of $4.5 \mathrm{~L}$ and that were filled with a substrate composed of a mixture of soil, sand and organic matter in a 3:1:1 ratio. Sowing was performed by applying the equivalent of $400.0 \mathrm{~kg}$ $\mathrm{ha}^{-1}$ NPK in a 4-30-16 formulation, and the soybean seeds were previously inoculated with the following strains of Bradyrhizobium japonicum: SEMIA 5079 and SEMIA 5080. In each pot, three seeds were seeded for each hybrid and parental combination. After the emergence of the $F_{1}$ seeds, the success of the hybridization was verified by the presence of anthocyanin pigmentation in the hypocotyl of the seedlings, and those plants resulting from selffertilization (no pigmentation) were eliminated, leaving $12 \mathrm{~F}_{1}$ plants for each combination. Irrigations were carried out twice a day manually, and control of diseases and pests was carried out weekly with the application of a fungicide (mancozebe, $3.0 \mathrm{~kg} \mathrm{ha}^{-1)}$ and an insecticide (thiamethoxam /lambda-cyhalothrin, $200.0 \mathrm{~mL} \mathrm{ha}^{-1}$ ).

The experimental design was a randomized complete block design, with four replications and 11 treatments (six hybrid combinations and five parents) and each plot consisted of a pot with three plants. The following characters were analyzed in each plant during the vegetative stages $\mathrm{R} 1$ and $\mathrm{R} 8$ according to the development scale proposed by Fehr and Caviness (1977): the number of days for flowering in stage R1 (NDF), the height of the plant in flowering at the R1 stage in centimeters (HPF), the number of nodes in flowering at stage R1 (NNF), the number of days to maturity at stage R8 (NDM), the height of the plant at maturity at the R8 stage in centimeters (HPM), the number of total nodes at maturity at stage R8 (NTN), the number of total pods at stage R8 (NTP) and the grain yield per plant in grams (GY).

The data were submitted to analysis of variance, and after obtaining the means of the crosses for the evaluated characters, partial diallel analysis was performed according to method 2 (parents and $F_{1}$ 's without reciprocals) of Griffing (1956) and adapted by Geraldi and Miranda Filho (1988). The effect of the treatments (means of six $F_{1}$ populations and five parents) was estimated by the mathematical model given below:

$Y_{i j}=\mu+\frac{1}{2}\left(d_{1}+d_{2}\right)+g_{i}+g_{j}^{\prime}+s_{i j}+\bar{\varepsilon}_{i j}$

in which

$Y_{i j}$ : mean of the crossing involving the $i$-th parent of group 1 and the $j$-th parent of group 2;

$\mathrm{Y}_{\mathrm{i} 0}$ : mean of the $\mathrm{i}$-th parent of group $1(\mathrm{i}=0.1, \ldots \mathrm{p})$;

$\mathrm{Y}_{0 \mathrm{j}}$ : mean of the $\mathrm{j}$-th parent of group $2(\mathrm{j}=0.1, \ldots \mathrm{p})$;

$\mu$ : general mean of the diallel;

$d_{1}, d_{2}$ : contrasts involving means of groups 1 and 2 , and the general average;

$\mathrm{g}_{\mathrm{i}}$ : effect of the general combining ability of the $\mathrm{i}$-th parent of group 1;

$g_{j}$ : of the general combining ability of the $j$-th parent of group 2;

$\mathrm{s}_{\mathrm{ij}}$ : effect of specific combining ability;

$\bar{\varepsilon}_{\mathrm{ij}}$ : mean experimental error.

The analyses of variance and diallel analysis were performed using the Genes program (Cruz, 2016).

\section{RESULTS AND DISCUSSION}

Significant effects were found in the diallel analysis for the general and specific combining abilities of the characters evaluated (Table 2). The significance of these parameters shows variability of the additive and non-additive gene effects among the genotypes, which can help in choosing better genitors and hybrid combinations for the development of superior genotypes. In addition, the general combining ability (GCA) occurs mainly due to additive variance and epistemic variance (additive-additive), while the specific combining ability (SCA) depends on the presence of dominance variance (Oliveira et al., 2014). These estimates can be useful in breeding programs since the selection of genitors and hybrid combinations with higher estimates of general combining ability (GCA) and specific combining ability 
(SCA) indicates the possibility of selecting genotypes with desirable characters, including those for grain yield.

GCA and SCA are fundamental for the identification of parents since these estimates are associated with high means and expressive magnitudes of genetic variability, resulting in ideal combinations for the formation of segregating populations with high genetic potential for lineage extraction (Pimentel et al., 2013). In all of the analyzed characters, except for HPM and NTN in group I, the GCA mean square was higher than that of the SCA (Table 2), indicating the predominance of additive gene effects for the control of character expression. Kurek et al. (2001) and Daronch et al. (2014) concluded that additive genetic effects were most important in determining characters in relation to non-additive effects, particularly for quantitative traits, which also allows successful selection in early generations. For the interaction between groups of parents, significance was observed only in the number of days for flowering.

In this study, the number of days for flowering had significant effects on both GCA and SCA. Bonato and Vello (1999) concluded that the main component determining the time for flowering is additive. For the number of days to maturity, the effects of GCA and SCA were significant and corroborated the results obtained by Oliveira et al. (2014).

For plant height at flowering and at maturity, there were significant effects on GCA only in group I (Table 2). Plant height is an important character for the genetic improvement of soybean since plants under $60 \mathrm{~cm}$ compromise grain yield and since plants above $90 \mathrm{~cm}$ are more susceptible to bedding (Sediyama et al., 2015). Significant effects on GCA and SCA were observed for flowering and maturity nodes.
The existence of additive effects for the number of total pods was verified only in group II (Table 2); thus, these genotypes present additives genes that contribute to the development of soybean lines that are more productive. This character is considered one of the most important production components because it has a direct effect on grain yield (Almeida; Peluzio; Afferri, 2010; Nogueira et al., 2012). For grain yield per plant, additive effects were significant only in group II, indicating the existence of additive variability for this character (Table 2). Regarding SCA, no significance was found, indicating that the performance of the hybrid combinations did not present differences with the genitors involved and that they are not contrasting for this trait. However, these findings do not agree with the results obtained by Daronch et al. (2014) and Oliveira et al. (2014), who reported significant effects on this character. The estimates of SCA characterize the complementation between genitors in relation to the frequency of dominant genes (Benin et al., 2009). Despite this, in soybean breeding, the additive effects are more important since the main goal is to obtain homozygous lines.

Choosing the best parents for the formation of segregating populations is crucial to the success of breeding programs. Thus, genotypes with high GCA estimates, positive or negative, show whether the parent in question is superior or inferior to the other parents in relation to the average behavior of the hybrid combinations indicating the predominance of genes with additive effects that can be included in breeding programs (Cruz; Regazzi; Carneiro, 2012; Daronch et al., 2014). Estimates of the effects of the general and specific combining abilities of the characters evaluated in this work are presented in Table 3.

Table 2: Summary of analysis of variance results for the partial diallel scheme involving two groups of parents and their respective hybrid combinations.

\begin{tabular}{cccrrrrrrr}
\hline \multirow{2}{*}{ SV } & \multirow{2}{*}{ DF } & \multicolumn{10}{c}{ MS } \\
\cline { 3 - 9 } & & NDF & HPF & NNF & NDM & HPM & NTN & NTP & GY \\
\hline Treatment & 10 & $84.87^{* *}$ & $783.86^{* *}$ & $7.86^{* *}$ & $381.46^{* *}$ & $952.65^{* *}$ & $6.47^{* *}$ & $513.46^{* *}$ & $20.00^{\text {ns }}$ \\
G1 x G2 & 1 & $14.88^{*}$ & $49.81^{\text {ns }}$ & $0.55^{\text {ns }}$ & $3.88^{\text {ns }}$ & $400.91^{\text {ns }}$ & $0.43^{\text {ns }}$ & $3.88^{\text {ns }}$ & $203.70^{\text {ns }}$ \\
GCA I & 1 & $82.57^{* *}$ & $412.57^{\text {ns }}$ & $7.14^{* *}$ & $658.29^{* *}$ & $257.14^{\text {ns }}$ & $4.57^{*}$ & $658.29^{\text {ns }}$ & $7.14^{\text {ns }}$ \\
GCA II & 2 & $128.22^{* *}$ & $1800.22^{* *}$ & $14.00^{* *}$ & $642.67^{* *}$ & $2248.22^{* *}$ & $8.22^{* *}$ & $1820.67^{* *}$ & $66.89^{* *}$ \\
SCA & 6 & $82.47^{* *}$ & $4.95^{* *}$ & $7.14^{* *}$ & $311.18^{* *}$ & $728.27^{* *}$ & $7.21^{* *}$ & $138.51^{\text {ns }}$ & $6.45^{\text {ns }}$ \\
Residue & 30 & 3.14 & 129.03 & 0.89 & 26.2 & 162.54 & 1.00 & 162.53 & 18.29 \\
\hline
\end{tabular}

**, *: significant to $1 \%$ and 5\% probability by the F test, respectively; ns: not significant; NDF: number of days for flowering; HPF: height of the plant in flowering; NNF: number of nodes in flowering; NDM: number of days to maturity; HPM: height of the plant at maturity; NTN: number of total nodes; NTP: number of total pods; GY: grain yield per plant; SV: source of variation; MS: mean square; DF: degree freedom; G1 x G2: interaction between group I and group II; GCA I: general combining ability for group I; GCA II: general combining ability for group II; SCA: specific combining ability. 
Table 3: Estimates of the effects of the general combining ability (GCA) and specific combining ability (SCA) of agronomic characters evaluated in a partial diallel.

\begin{tabular}{|c|c|c|c|c|}
\hline \multicolumn{5}{|c|}{ Number of days for flowering } \\
\hline \multirow{2}{*}{ Parental } & \multicolumn{4}{|c|}{ SCA } \\
\hline & TMG 4182 & TMG 4185 & BRSGO Chapadões & GCA I \\
\hline UFUS 7910 & -5.62 & -5.96 & 0.88 & 1.21 \\
\hline BR/MG 46 Conquista & 0.81 & -1.50 & -1.69 & -1.21 \\
\hline GCA II & -1.94 & -0.61 & 2.56 & \\
\hline \multicolumn{5}{|c|}{ Height of the plant in flowering } \\
\hline \multirow{2}{*}{ Parental } & \multicolumn{4}{|c|}{ SCA } \\
\hline & TMG 4182 & TMG 4185 & BRSGO Chapadões & GCA I \\
\hline UFUS 7910 & -16.86 & -14.69 & 7.30 & 2.71 \\
\hline BR/MG 46 Conquista & 0.57 & -6.27 & -2.27 & -2.71 \\
\hline GCA II & -5.89 & -4.06 & 9.94 & \\
\hline \multicolumn{5}{|c|}{ Number of nodes in flowering } \\
\hline \multirow{2}{*}{ Parental } & \multicolumn{4}{|c|}{ SCA } \\
\hline & TMG 4182 & TMG 4185 & BRSGO Chapadões & GCA I \\
\hline UFUS 7910 & -1.86 & -1.36 & 0.64 & 0.36 \\
\hline BR/MG 46 Conquista & -0.14 & -0.64 & -0.64 & -0.36 \\
\hline GCA II & -0.67 & -0.17 & 0.83 & \\
\hline \multicolumn{5}{|c|}{ Number of days to maturity } \\
\hline \multirow{2}{*}{ Parental } & \multicolumn{4}{|c|}{ SCA } \\
\hline & TMG 4182 & TMG 4185 & BRSGO Chapadões & GCA I \\
\hline UFUS 7910 & -9.87 & -12.54 & 2.79 & 3.43 \\
\hline BR/MG 46 Conquista & 0.98 & 0.31 & -6.35 & -3.43 \\
\hline GCA II & -5.33 & 0.33 & 5.00 & \\
\hline \multicolumn{5}{|c|}{ Height of the plant at maturity } \\
\hline \multirow{2}{*}{ Parental } & \multicolumn{4}{|c|}{ SCA } \\
\hline & TMG 4182 & TMG 4185 & BRSGO Chapadões & GCA I \\
\hline UFUS 7910 & -19.61 & -16.44 & 10.39 & 2.14 \\
\hline BR/MG 46 Conquista & 3.68 & 1.85 & -0.32 & -2.14 \\
\hline GCA II & -6.94 & -4.11 & 11.06 & \\
\hline \multicolumn{5}{|c|}{ Number of total nodes } \\
\hline \multirow{2}{*}{ Parental } & \multicolumn{4}{|c|}{ SCA } \\
\hline & TMG 4182 & TMG 4185 & BRSGO Chapadões & GCA I \\
\hline UFUS 7910 & -1.99 & -1.49 & 0.84 & 0.29 \\
\hline BR/MG 46 (Conquista) & 0.58 & 0.08 & 0.42 & -0.29 \\
\hline GCA II & -0.56 & -0.06 & 0.61 & \\
\hline
\end{tabular}


Table 3: Continuation.

\begin{tabular}{ccccc}
\hline \multicolumn{5}{c}{ Number of total pods } \\
\hline Parental & \multicolumn{5}{c}{ SCA } \\
\hline TMG 4182 & TMG 4185 & BRSGO Chapadões & GCA I \\
\hline UFUS 7910 & -10.48 & -2.65 & 0.18 & 3.43 \\
BR/MG 46 Conquista & 3.37 & -3.79 & 0.40 & -3.43 \\
\hline GCA II & -8.17 & -1.00 & 9.17 \\
\hline \multicolumn{5}{c}{ Grain yield per plant } \\
\hline Parental & TMG 4182 & TMG 4185 & BRSGO Chapadões & GCA I \\
\hline UFUS 7910 & -1.94 & 1.56 & 0.72 & -0.35 \\
BR/MG 46 Conquista & 1.35 & -0.15 & 0.13 & 0.35 \\
\hline GCA II & -1.61 & -0.11 & 1.72 \\
\hline
\end{tabular}

Positive, high magnitude estimates of the general combining ability were observed in group I for the UFUS 7910 parent, with values between 0.29 (NTN) and 3.43 (NDM), and for BR/MG 46 Conquista, with 0.35 for grain yield, while in group II, it was verified that the GCA of BRSGO Chapadões ranged from 0.61 (NTN) to 11.06 (HPM) (Table 3). The GCA estimates presented for the other parents were negative. Thus, the cultivars BRSGO Chapadões, UFUS 7910 and BR/MG 46 Conquista were considered genetically superior to the others evaluated in this study, and their GCA estimates indicate that they should participate in crossings.

The formation of base populations from the parents BR/MG 46 Conquista and BRSGO Chapadões demonstrates viability for generating higher segregating populations, especially for the total number of pods and grain yield per plant. Therefore, the combination of genotypes with estimates of general combining ability with positive and high magnitudes contributes to the formation of genetically superior populations due to the greater presence of genes with additive effects, which is fundamental for soybean, where obtaining lines with high performance for quantitative characters is desirable. However, a positive estimate of SCA for grain yield per plant was found in the hybrid combination TMG 4185 x UFUS 7910, and both genitors presented negative estimates of GCA (Table 3 ). In this case, the effect presented was non-additive, indicating a predominance of dominant genes and a heterotic effect for this character.

When a reduction in the expression of a character is desired, at least one of the parents must present negative GCA values (Krause; Rodrigues; Leal, 2012).
Parental TMG 4182 and BR/MG 46 Conquista presented GCA estimates of -1.94 and -0.67 for NDF and -5.33 and -3.43 for NDM, respectively, indicating that these genotypes contributed to the reduction in cycling in relation to UFUS 7910 and BRSGO Chapadões (Table 3).

In relation to the other characters analyzed, the cultivars TMG 4182 and TMG 4185 presented negative GCA estimates mainly for plant height to flowering and to maturity, number of total nodes, number of total pods and grain yield per plant, indicating that the use of these genotypes in crosses leads to the development of populations with low productivity (Table 3 ).

Positive estimates of SCA were observed in the combinations TMG 4182 x UFUS 7910, TMG $4182 \mathrm{x}$ BR/MG 46 Conquista, BRSGO Chapadões x UFUS 7910 and BRSGO Chapadões $\mathrm{x}$ BR/MG 46 Conquista (Table 3). The positive SCA values indicate that these hybrid combinations present dominant genes that contribute to grain yield and other characters. Meanwhile, negative estimates and high magnitudes were found for TMG $4182 \mathrm{x}$ UFUS 7910 for all traits (Table 3). These negative estimates indicate that the performance of the hybrid combination is inferior to those of the parents mainly for the total number of pods and grain yield per plant.

\section{CONCLUSIONS}

The BR/MG 46 Conquista, UFUS 7910 and BRSGO Chapadões parents presented additive effects that can contribute to obtaining productive segregant populations in accordance with their general combining abilities. The hybrid combination BRSGO Chapadões $\mathrm{x} \mathrm{BR} / \mathrm{MG} 46$ Conquista is promising for obtaining a 
population with high productive potential mainly for the number of total pods and grain yield per plant. The combinations BRS Chapadões x UFUS 7910 and BR/ MG 46 Conquista $x$ TMG 4182 can be used to develop segregant populations for grain yield since the estimates of general combining ability were positive for at least one parent.

\section{ACKNOWLEDGMENT}

We thank the Foundation for Research Support of the State of Minas Gerais for granting a scholarship during the completion of the PhD course in Agronomy.

\section{REFERENCES}

AKRAM, S. et al. variability and association analysis of soybean (Glycine max (l.) Merrill) for yield and yield attributing traits. Plant Gene and Trait, 7(13):1-11, 2016.

ALMEIDA, R. D.; PELUZIO, J. M.; AFFERRI, F. S. Correlações fenotípicas, genotípicas e ambientais em soja cultivada sob condições várzea irrigada, Sul do Tocantins. Bioscience Journal, 26(1):95-99, 2010.

BENIN, G. et al. Capacidade de combinação em genótipos de trigo estimada por meio de análise multivariada. Pesquisa Agropecuária Brasileira, 44(9):1145-1151, 2009.

BERTAN, I.; CARVALHO, F. I. F.; OLIVEIRA, A. C. Parental selection strategies in plant breeding programs. Journal of Crop Science and Biotechnology, 10(4):11-222, 2007

$\mathrm{BI}, \mathrm{Y}$. et al. Heterosis and combining ability estimates in isoflavone content using different parental soybean accessions: Wild soybean, a valuable germplasm for soybean breeding. Plos One, 10(1):1-13, 2015.

BONATO, E. R.; VELLO, N. A. Aspectos genéticos do tempo para o florescimento em variantes naturais de soja. Pesquisa Agropecuária Brasileira, 34(6):989-993, 1999.

CRUZ, C. D. Genes Software: Extended and integrated with the R, Matlab and Selegen. Acta Scientiarum. Agronomy, 38(4):547-552, 2016.

CRUZ, C. D.; REGAZZI, A. J.; CARNEIRO, P. C. S. Modelos biométricos aplicados ao melhoramento genético. 4. ed. Viçosa: UFV, 2012. 514p.

DARONCH, D. J. et al. Capacidade combinatória de cultivares de soja em $F_{2}$, sob condições de cerrado tocantinense. Bioscience Journal, 30(5):688-695, 2014.

FEHR, W. R.; CAVINESS, C. E. Stages of soybean development. Ames: lowa State University, 1977. (Special Report, 80). 11p.
GARDNER, C. O.; EBERHART, S. A. Analysis and interpretation of the variety cross diallel and related populations. Biometrics, 22(3):439-452, 1966.

GERALDI, I. O.; MIRANDA FILHO, J. B. Adapted models for the analysis of combining ability of varieties in partial diallel crosses. Revista Brasileira de Genética, 11(2):419-30, 1988.

GRIFFING, B. Concept of general and specific combining ability in relation to diallel crossing systems. Australian Journal of Biological Science, 9(4):463-493, 1956.

HAYMAN, B. I. The theory an analysis of diallel crosses. Genetics, 39(6):789-809, 1954.

KEMPTHORNE, O.; CURNOW, R. N. The partial diallel cross. Biometrics, 17(2):229-250, 1961.

KRAUSE, W.; RODRIGUES, R.; LEAL, N. R. Capacidade combinatória para caracteres em feijão-de-vagem. Revista Ciência Agronômica, 43(3):522-531, 2012.

KUREK, A. J. et al. Capacidade combinatória como critério de eficiência na seleção de genitores em feijoeiro. Pesquisa Agropecuária Brasileira, 36(4):645-651, 2001.

NAGARAJAN, D.; KALAIMAGAL, T.; MURUGAN, E. Combining ability analysis for yield component and biochemical traits in soybean [Glycine max (L.) Merrill]. International Journal of Current Microbiology and Applied Sciences, 6(11):2894-2901, 2017.

NOGUEIRA, A. P. O. et al. Análise de trilha e correlações entre caracteres em soja cultivada em duas épocas de semeadura. Bioscience Journal, 28(6):877-888, 2012.

OLIVEIRA, I. J. et al. Diallel among soybean genotypes with high oil content and resistance to sudden death syndrome. Brazilian Archives of Biology and Technology, 57(2):178-186, 2014.

PAINKRA, P.; NAG, S. K.; KHUTE, I. Identification of best combiners for soybean improvement at Chhattisgarh Plains. International Journal of Current Microbiology and Applied Sciences, 6(11):478-482, 2017.

PIMENTEL, A. J. B et al. Comparação de métodos de seleção de genitores e populações segregantes aplicados ao melhoramento de trigo. Bragantia, 72(2):113-121, 2013.

ROCHA, G. A. F.; PEREIRA, F. A. C.; VELLO, N. A. Potential of soybean crosses in early inbreeding generations for grain yield. Crop Breeding and Applied Biotechnology, 18(3):267-275, 2018.

SEDIYAMA, T. et al. Características agronômicas de cultivares. In. SEDIYAMA, T. (Ed.). Melhoramento genético da soja. Londrina: Mecenas, 2015. p.73-82. 